\title{
Rethinking urban green infrastructure and ecosystem services from the perspective of sub-Saharan African cities
}

DOI:

10.1016/j.landurbplan.2018.08.016

\section{Document Version}

Accepted author manuscript

Link to publication record in Manchester Research Explorer

Citation for published version (APA):

Lindley, S., Pauleit, S., Yeshitela, K., Cilliers, S., \& Shackleton , C. (2018). Rethinking urban green infrastructure and ecosystem services from the perspective of sub-Saharan African cities. Landscape and Urban Planning. https://doi.org/10.1016/j.landurbplan.2018.08.016

\section{Published in:}

Landscape and Urban Planning

\section{Citing this paper}

Please note that where the full-text provided on Manchester Research Explorer is the Author Accepted Manuscript or Proof version this may differ from the final Published version. If citing, it is advised that you check and use the publisher's definitive version.

\section{General rights}

Copyright and moral rights for the publications made accessible in the Research Explorer are retained by the authors and/or other copyright owners and it is a condition of accessing publications that users recognise and abide by the legal requirements associated with these rights.

\section{Takedown policy}

If you believe that this document breaches copyright please refer to the University of Manchester's Takedown Procedures [http://man.ac.uk/04Y6Bo] or contact uml.scholarlycommunications@manchester.ac.uk providing relevant details, so we can investigate your claim.

\section{OPEN ACCESS}


1 Rethinking urban green infrastructure and ecosystem services from the perspective of sub-

2 Saharan African cities.

3

4 Lindley, S., Pauleit, S., Yeshitela, K., Cilliers, S.S., Shackleton, C.

5 <Authors originally removed for peer review>

6

7 [Narrative Review]

8

9 Abstract: Urban green infrastructure and its ecosystem services are often conceptualised in terms

10 of a predominantly western perspective of cities and their wider social, economic and

11 environmental challenges. However, the benefits which are derived from urban ecosystems are

12 equally - if not more - important in the cities of the developing world. Cities in sub-Saharan

13 Africa are well known to be facing severe pressures. Nevertheless, despite the challenges of rapid

14 population change, high levels of poverty and seemingly chaotic urban development processes,

15 there are also tremendous opportunities. Realising the opportunities around urban green

16 infrastructure and its benefits requires harnessing the inherent local knowledge and community

17 innovation associated with a multitude of inter-connected urban social-ecological systems. Such

18 systems are a powerful driving force shaping urban realities. Associated planning regimes are

19 frequently lambasted as being either absent, weakly enforced, corrupt or wholly inappropriate.

20 Much of this criticism is justified. However, it must also be recognised that decision-makers are

21 frequently working in contexts which lack the scientific foundations through which their

22 decision-making might be made more effective and complementary to bottom-up initiatives. The

23 paucity of research into urban ecosystems in sub-Saharan Africa and the lack of development of 
24 context-specific conceptual, theoretical and empirical foundations is a problem which must be

25 addressed. Drawing on papers from a Special Issue centred on urban green infrastructure and 26 urban ecosystem services in sub-Saharan Africa, we consider what concepts and frameworks are

27 in use and what needs to be considered when framing future research. We also synthesise key

28 messages from the Special Issue and draw together themes to help create a new research agenda

29 for the international research community.

31 Key words: green infrastructure, ecosystem benefits, urban settlements, frameworks, review,

32 Africa

34 Research highlights

35

36

- A transdisciplinary research agenda \& synthesis of key messages from our Special Issue

- Research on Africa's urban green infrastructure \& its benefits uses many frameworks

- Not all frameworks currently recognise Africa's distinctive urban characteristics

- We propose a ten point list for developing novel, context-specific frameworks

- The few relatively well researched African cities are beacons for future activity 
43 Forty years ago, Richard L. Meier identified the requirements for a 'stable urban ecosystem' in

44 the developing world. For him, the urban ecosystem comprised all components of emerging

45 cities, including their populations, food and transport systems, industry and commerce (Meier,

46 1976). His ideas were different to, but still aligned with, more recent ideas around urban green

47 infrastructure (GI) and associated ecosystem 'services'. The need to consider the

48 interrelationships between people and the environment and urban areas as social-ecological

49 systems is now well recognised (Pickett et al., 2011). In a world which is both more populous and

50 more urban, these ideas are growing in popularity and importance. Nevertheless in some parts of

51 the world, research and associated knowledge exchange on these themes remains limited

52 (Elmqvist et al., 2013; Haase et al., 2014). There are many possible reasons, including ones

53 which stem from differences in social, cultural, environmental and resource contexts. In sub-

54 Saharan Africa (which we will hereafter refer to as Africa), a lack of institutional capacity and

55 perceived relevance together with a whole gamut of 'more pressing' concerns ensure that

56 priorities around urban green and blue spaces and the benefits that they bring to urban dwellers

57 are commonly lost or never considered (Herslund, et al., 2017). For some, "The notion that

58 ecosystem services ... should form the foundation of city planning flies in the face of the current

59 practice in almost every African city over the last century, where the resilience of the nature

60 resource base has been taken for granted" (Blanco et al., 2009, p. 240). Undoubtedly, this

61 situation is not helped by the development of conceptual principles and practical examples based

62 on very different urban settings than those characterising the Global South and where there are

63 already robust criticisms of failures in urban planning regimes. Such failures are attributed to the

64 tendency for planning regimes to exist as either legacy instruments from colonial times or

65 imported models and frameworks which proved to be ill-suited to the emerging realities of urban 
66 Africa (Anderson, Okereke, Rudd, \& Parnell, 2013; Blanco et al., 2009; UN-HABITAT, 2014).

67 In its 2014 State of African Cities report, UN-Habitat calls for a 'radical re-imagining' of current

68 systems in order to inspire innovation, mitigate problems and harness benefits (UN-HABITAT,

69 2014). This begs the question of whether concepts like urban GI and ecosystem services are

70 simply more of the same or whether they might form part of the foundation and inspiration for a

71 revolution in thinking and action in African towns and cities.

72 Arguably, urban ecosystem services - as the beneficial ecosystem functions required for human

73 wellbeing - are more important in the context of many African cities than anywhere else. Yet, it

74 is in these contexts that research is particularly scant with a clear bias to South African cities

75 (Cilliers, Cilliers, Lubbe, \& Siebert, 2013; du Toit et al., 2018; Smit \& Parnell, 2012). This is not

76 to assume that no relevant research exists, just that much of it remains outside of the international

77 peer-review literature (Cavan et al., 2012). Furthermore, there is a great deal of informal

78 knowledge residing within local communities (Elmqvist et al., 2013). The papers in this Special

79 Issue (SI) highlight the close relationships between urban populations and ecosystem services in

80 Africa (e.g. Roy et al., 2018), the marked inequalities that exist in access to some services (e.g.

81 McConnachie \& Shackleton, 2010; McConnachie, Shackleton, \& McGregor, 2008) and the very

82 different status and diversity that associated green structures can have (e.g. Anderson et al., 2013;

83 Cilliers et al., 2013). Although there are commonalities between the services which are provided

84 in different cities the world over, in the context of urban Africa, there are also distinct differences

85 (Davoren, Siebert, Cilliers, \& du Toit, 2015; Shackleton, 2012). For example, urban agriculture

86 provides a literal life-line for many of the poorest members of society in urban Africa (e.g. Abo-

87 El-Wafa, Yeshitela, \& Pauliet, 2017). However, the sheer pace of development in this part of the

88 world is threatening the very existence of this productive green space and the ecosystem services 
89 upon which the livelihoods and wellbeing of the urban poor largely depend (e.g. Lindley et al.,

90 2013; Printz, Abo El Wafa, Buchta, \& Pauleit, 2015).

91 The composition and extent of green structures themselves also affect the urban ecosystem

92 services which are provided. Many African cities still retain significant remnants of native 93 ecosystems and plant assemblages. Although often degraded, they provide a buffering function

94 for natural hazards, e.g. in the case of mangroves for coastal flooding or native flora on wooded

95 slopes and river banks in Addis Ababa (Cavan et al., 2012; Gómez-Baggethun et al., 2013), as

96 well as safety-nets against economic and assets shocks (Sachikonye, 2014). Studies from South

97 African cities in biodiversity hotspots of international importance (e.g. Cape Town and Durban)

98 have indicated how ecosystem services of fragmented natural areas need to be assessed and

99 valued to show their importance for inclusion in urban planning and management (De Wit et al., 100 2012; O’Farrell, Anderson, Le Maitre, \& Holmes, 2012; Roberts, Boon, Croucamp, \& Mander, 101 2005). However, rapid rates of development and lack of enforcement of regulations means that 102 the continued availability of services cannot be guaranteed, even where their city-wide 103 importance is well recognised in academic and policy circles (Anderson et al., 2013). Efforts to 104 re-establish and protect native ecosystems are often in evidence but face pressures from 105 environmental change, the demands of economic and political agendas and the lack of firm 106 enforcement of plans, policies and regulations. However, there are some success stories and an 107 ever-improving understanding of underlying issues and how they can be tackled (e.g. Herslund et 108 al., 2017). This SI brings together further evidence generated from formal projects, published 109 literature and from more informal knowledge bases, including some which have been built up 110 over decades (Douglas, 2016). 
111 The nature and extent of pressure from development is an obvious source of differences between

112 urban areas in Africa and those in the Global North (du Toit et al., 2018). However, just as rapid

113 change and urban expansion can lead to losses, there are also opportunities for establishing green

114 structures and services which are rare, if not entirely absent, in developed cities. For example, the

115 Addis Ababa City Beautification, Park and Cemetery Development Agency plans to establish

116 multiple new parks across the city, though realising them in practice can still be a challenge

117 (Assefa, 2013; Jemaneh, 2017). Initiatives in Addis Ababa include examples which have

118 biodiversity and ecosystem services goals, including medicinal plant schemes and schemes

119 involving the rehabilitation of the upper river catchments in the northern fringes of the city using

120 biological and physical measures (Cavan et al., 2012; Yohannes and Elias 2017). Over the past

121 ten years the schemes have helped to bring back the native flora (e.g. Juniperus procera, Hagenia

122 abyssinica, Rosa abyssinica) using soil seed banks and enrichment plantations. In turn the

123 improvements are helping to provide wider ecosystem services, for example several springs are

124 reappearing and being used as potable water for nearby residents and holy water for followers of

125 the Ethiopian Orthodox Church. Although not a specific theme in this SI, examples like this

126 underline the importance of the connections between biodiversity and ecosystem services,

127 something which may be particularly strong in Africa.

129 In concluding this SI, we complement the review of urban GI and ecosystem services in Africa 130 used to open it (du Toit et al., 2018). Inevitably there is some overlap between our messages.

131 However, here we also look back over the SI and reflect on what more the contributing papers 132 reveal as a whole, assess what knowledge gaps remain and consider how gaps might be bridged 133 in the future. Such an assessment involves thinking through the implicit assumptions behind the 134 terms and ideas shaping this field of study. Through shining a light on implicit assumptions, it is 
135 hoped that researchers will recognise them better and consider them more explicitly in future

136 studies. Researchers will then be better placed to consider how to represent the specific contexts

137 of diverse African cities more effectively, to address science, policy and practice challenges and

138 to harness opportunities for maximum benefit.

140 The remainder of our paper is structured into two parts. Part 1 provides a brief summary of how

141 notions of GI and ecosystem services have been developed and conceptualised. Notably, this

142 draws from work which has been mainly carried out in the Global North. Part 2 considers what is

143 learnt from the research presented in this SI through addressing three related questions:

144 - What does this SI further reveal about GI and urban ecosystem services in African cities?

145 - How have related concepts and frameworks been used and might be adapted to provide a

146 better foundation for research and practice in African cities?

147 - How far does this SI help to address gaps and what future research agendas emerge?

2. Methods

150 Part 1 is informed by a semi-structured review of the academic literature. An overview of the 151 terms urban GI and urban ecosystem services and some of the frameworks and ideas with which 152 they are associated was developed from accessing 24 review papers published before 2017. 153 Candidate papers were identified using the search term "review" with "framework" and with one 154 of "urban ecosystem services", "urban green infrastructure", "social-ecological systems", "urban 155 ecology" "urban environment* planning" or "urban landscape planning". Concepts are therefore 156 extracted from papers explicitly aiming to frame issues around GI and urban ecosystem services. 157 These papers can be expected to inform studies in the topic area of this SI. Papers were excluded 158 where the review was primarily on empirical evidence and not on framings, centred on a 
159 narrowly-defined thematic focus, e.g. green facades, and/or explicitly focussed on geographical

160 settings demonstrably outside of the remit of this SI. From this shortlist, a snow-balling approach

161 was used to identify additional key texts which were further supplemented with papers identified

162 by each of the authors. A fully exhaustive and systematic review was beyond the scope of this

163 particular article. The selection of papers drew on recognised protocols for systematic reviews

164 but can only be considered partially systematic in this case (Pullin \& Stewart, 2006). All

165 literature searches were carried out using Web of Science to identify English-language sources in

166 the peer reviewed, scientific literature. It is recognised that this may exclude influential sources

167 not held within these sorts of bibliographic databases. Equally, there are variants in terms which

168 may also have unintentionally excluded some sources, e.g. "ecological planning”. Given that our

169 intention is to summarise the nature and foundation of terms and associated frameworks, these

170 limitations are considered to be acceptable.

171 The review aims to provide insights into the theoretical basis upon which most current studies on

172 African GI and ecosystem services are likely to be based. Due to a lack of review papers on 173 frameworks explicitly and solely centred on urban GI and ecosystem services in African cities,

174 there is limited reference to Africa in Part 1. This is not to imply that there is no theory, rather it 175 notes that the theory does not appear to have been systematically reviewed as yet. By extension, 176 it can be assumed that framings - whether standard or refined - tend to be identified on a case-by-

177 case basis. Given these assumptions and limitations, the review then sets the scene for addressing

178 the questions for Part 2. The questions were derived with reference to previous review papers 179 (Binder, Hinkel, Bots, \& Pahl-Wostl, 2013; Haase et al., 2014). 
182 There are numerous frameworks used to guide thinking in the complex, multi-faceted and

183 transdisciplinary arena of urban GI and urban ecosystem services. As structured sets of concepts,

184 assumptions and relationships, frameworks can be conceptual, analytical or process based, but all

185 act as the foundation for understanding a particular view of reality (after Binder et al., 2013).

186 Frameworks are therefore informed by disciplinary specialisms which reflect the particular

187 world-views of researchers and their epistemological, ideological or contextual underpinnings. In

188 other words they can be influenced by academic backgrounds and traditions, modes of

189 knowledge generation, personal goals and mind-sets and socio-political and cultural settings. For

190 example, urban areas can be seen as everything from 'parasites in the biosphere' (Odum, 1971,

191 cited in Bolund \& HunHammer, 1999) to opportunities for social reform (Ebenezer Howard,

192 1898, as discussed in Maruani \& Amit-Cohen, 2007).

193 Despite this multiplicity - or perhaps because of it - there is now a concerted effort to

194 accommodate different perspectives around urban GI. This is certainly a work in progress, but a

195 range of frameworks have evolved which consider urban areas to be firmly social-ecological

196 systems of one form or another. One element of this convergence process has been nicely

197 summarised as a meeting between ecological and ecology-related schools of thought with

198 planning and planning-related schools of thought so that the former move from ecology in the

199 city to ecology of the city and the latter from planning of the city to planning in the city (Gómez-

200 Baggethun et al., 2013; Pickett et al., 2011). The concept of GI and its ecosystem services and the

201 ever closer ties they make between landscape ecology and spatial planning might then be seen as

202 a logical outcome of this process (Gómez-Baggethun et al., 2013). Another element of the

203 convergence process towards social-ecological systems is, of course, that ever closer ties are

204 made between people and ecosystems. The underlying thinking becomes inherently orientated to

205 an anthropocentric view given that human health and wellbeing tends to be emphasised over 
ecosystem 'health', i.e. the conservation, maintenance and enhancement of biodiversity and

207 ecosystem functionality (Tzoulas et al., 2007). Even as a supposed human-orientated construct,

208 evidence suggests that key principles remain under-developed. For example, from 84 ecosystem

209 service frameworks published 1987-2014, 62\% did not consider human health and only a quarter

210 considered interactions between human and ecosystem health (Ford, Graham, \& White, 2015).

211 The traction of this particular terminology has been aided considerably by its adoption by major

212 initiatives such as the Millennium Ecosystem Assessment (MEA) and The Economics of

213 Ecosystems and Biodiversity (TEEB) (TEEB, 2011; Rall, Kabisch, \& Hansen, 2015). Such work

214 makes the economic principles that informed the development of the concept of ecosystem

215 services all the more explicit (Costanza et al., 1997; de Groot, 1987). For some, this is a strong

216 point of contention, but by no means the only one. Schroter et al. (2014) discuss no fewer than

217 seven arguments against the use of ecosystem services as a concept. Arguments include: the

218 prioritisation of people over ecosystems; the commodification of nature and encouragement of

219 exploitative practices; and the promotion of a framework which is at the same time vague and

220 also normative. These concerns have not halted the growing popularity of the term in academic or

221 practitioner circles, with several national and supranational assessments in Europe already

222 adopting ecosystem services assessment and associated economic valuation methods to help to

223 fill a void in how to meaningfully connect issues around 'nature' with everything else - i.e. in

224 prevalent socio-political contexts (Rall et al., 2015). Developing appropriate modes of valuation

225 as well as evaluation of urban ecosystem services are still very much an area of current research,

226 e.g. to recognise the limits of monetary valuation, the range of 'value domains' involved and

227 ways of recognising the value of biodiversity (Gómez-Baggethun \& Barton, 2013; Knippenberg

228 et al., 2015). Complementary concepts such as bio-cultural diversity have also been proposed to 
230 the inter-connectedness and inter-dependencies of cultural and natural systems and is highly

231 relevant to this review due to its provenance, i.e. developed from research into livelihoods and 232 nature conservation in the Global South.

233 These issues are pertinent for research into GI and associated ecosystem services for Africa cities

234 as they have implications for the suitability of its framing. In some cases the assumptions may

235 not fit well with the contexts of their application or they may have particularly problematic

236 consequences for onward use. For example, how far is an emphasis on traditional planning

237 processes helpful and what sort of problems may result from an emphasis on economic costing 238 models in a quick moving, informal economy with few safeguards on development in 'protected' 239 areas?

240 The Inter-governmental Platform for Biodiversity and Ecosystem Services (IPBES) - itself a 241 science-governmental partnership - is now a major proponent of 'ecosystem services', albeit with 242 an evolution of some of the terms and language, e.g. to fit with traditions outside of western 243 scientific culture. This latter distinction is important, though, when it comes to framing 244 assessments which value the range of contexts within which knowledge is produced and learning 245 applied (Díaz et al., 2018). Therefore, how biodiversity and ecosystem services are being 246 interpreted for IPBES (Díaz et al., 2015; 2018) is a major consideration. The second important 247 aspect here is the emphasis on biodiversity. Some argue that the role and value of biodiversity, 248 both for conservation and also benefits to urban dwellers is still only weakly understood 249 (Shwartz, Turbe, Julliard, Simon, \& Prevot, 2014) and 'green planning' approaches should not be 250 at the expense of the promotion of interventions at the micro-scale that address biodiversity, 251 multi-functionality and wider human benefits. There is a case for conservation in urban areas but 252 the main motivations are somewhat unclear or not currently fully tested, such as for in situ 
253 species conservation, for migration through corridors and stepping stones, for benefits to people

254 through cultural and other ecosystem services or for conservation education. Some of these 255 motivations echo how the framing of conservation has changed over time, how multiple 256 interpretations now co-exist (Mace, 2014) and how they reflect a range of legitimate perspectives.

257 Conceptualising urban social-ecological systems requires an assessment of what system is in

258 focus and how it can be understood (Gómez-Baggethun et al., 2013). In the context of this SI, it

259 is interesting to explore how far authors analyse the term 'urban' and what terms and ideas are 260 used to understand and represent African urban green and blue landscapes. In the wider literature 261 some discussions are framed around 'open space' (Maruani \& Amit-Cohen, 2007), others 'green 262 and blue' space (Bolund \& and HunHammer, 1999; Gómez-Baggethun et al., 2013). Such spaces 263 are often translated into land units, frequently as discrete and bounded land parcels (Gill et al., 264 2008; Huang et al., 2015; Pickett et al., 2011). Land parcels are used for several reasons. Firstly, 265 they make logical sense from the perspective of land use planning regimes and the historical 266 urban development processes which generally prevail in the Global North. Secondly, bounded 267 land parcels facilitate the development of indices that draw on a variety of existing databases and 268 allow social-ecological processes to be considered together, e.g. in ecosystem service 'bundles' 269 (Elmqvist et al., 2013; Pickett et al., 2011). Finally, they provide a way for knowledge and 270 knowledge generation to be translated into a form assumed to be suitable for application in 271 practice, i.e. meaningful for practitioners. Delineation of appropriate units and the consideration 272 of units also helps to make the need to consider spatial scale more explicit (Elmqvist et al., 2013;

273 Pickett et al., 2011). In turn, this allows some consideration of the effects of aggregation and 274 zonation on related assessments and analyses, i.e. the Modifiable Area Unit Problem (Dark and 275 Bram, 2007; Openshaw, 1984). The urban landscape planning and urban ecology traditions 276 further emphasise spatial dimensions, through for example Forman and Godron's patch-corridor- 
277 matrix model (Forman \& Godron, 1986) and McHarg's “Design with Nature”(McHarg, 1969).

278 Among other things "Design with Nature" was a guiding basis for the development of layer279 based processing in Geographical Information Science (GISc) (de Smith, Longley, \& and 280 Goodchild, 2013). Unsurprisingly, then, GISc is an important influence on practice in some of 281 these fields and can provide methodological framing as well as influencing what sorts of data are 282 used and why. What sorts of land unit representations are used in Africa, how and why they are 283 generated, what influence they have on findings and what assumptions do they contain?

284 Evidence suggests that GI relevant typologies can be constructed and used to delineate 285 appropriate land units for analysis (Lindley et al., 2015). However, the complex and 286 heterogeneous nature of African development (Lupala, 2002; Mosha \& Mosha, 2012) mean that 287 many zones are in practice 'mixed', especially when applied to intermediate 'neighbourhood' 288 scale geographies across large cities. For some of the five African cities analysed in (Lindley et 289 al., 2015), characterisation using Urban Morphology Types resulted in some very large zones and 290 difficulties in distinguishing between urban and rural. In addition, there is the issue of availability 291 of appropriate, contemporary data at sufficiently high resolution and lack of access to appropriate 292 resources and capacities locally to undertake data analysis in the frequencies required to generate 293 updates to match the rapid state of flux in many African urban areas, particularly where urban 294 sprawl results in large increments in the physical sizes of cities (Seto, Guneralp, \& Hutyra, 2012).

295 Understandings about urban ecosystem services are therefore equally sensitive to spatial scale.

296 Since we are ultimately considering systems, time is also important. The benefits of urban GI and 297 ecosystem services are time sensitive and they also evolve over time. Therefore a refined 298 understanding of temporal dimensions is needed in order to consider the dynamics of inter299 relationships within and between social and ecological systems (Raffaelli \& White, 2013). 
300 Despite this, a surprising $82 \%$ of ecosystem services frameworks appear not to consider time

301 (Ford et al., 2015), with only 5\% having refined conceptualisations. The importance of the 302 temporal dimensions of studies has been recognised in many of the reviews considered here. That

303 importance is further heightened in the case of African cities because of the very high rates and 304 complex patterns of change in urban populations and the spaces they use and hence demands for

305 land, services and infrastructure. These high rates mean the situation can change very rapidly.

306 Frameworks where time is handled in a refined way may therefore be particularly helpful for the

307 African urban context.

308 Models are an obvious way of operationalising the temporal dimensions of frameworks. They 309 help to move assessments away from 'mere' empirical foundations and can also challenge linear 310 thinking and outcomes based only on prior experience (Pickett et al., 2011). Models allow the 311 exploratory 'what if' and idealised 'if only' scenarios to be examined and provide a foothold into 312 understanding possible outcomes from a range of possible future trajectories. However, since

313 models of land-use change are still limited in terms of feedback between social and ecological 314 elements, this does restrict what is possible in practice (Elmqvist et al., 2013). Currently, there is 315 little opportunity to fully explore inter-related spatial and temporal dynamics and social316 ecological processes operating on different scales. Even if there were, complex spatial and 317 temporal framing becomes highly resource and data intensive and therefore a challenge even in 318 the context of relatively well researched cities (Gómez-Baggethun et al., 2013; Maruani \& Amit319 Cohen, 2007). Nonetheless, a consideration of what sorts of time frames underpin studies and the 320 assumptions that this brings into knowledge bases does need to be made. Decisions about the 321 relative importance of space and time may be influenced by disciplinary outlook which further 322 underlines the need for ambitious inter-disciplinary thinking in this arena. 
323 Both GI and ecosystem services have been defined within this SI volume (du Toit et al., 2018)

324 but the discussion is summarised and extended here as a basis for further analysis. GI can be 325 defined as "an interconnected network of green space that conserves natural ecosystem values 326 and functions and provides associated benefits to human populations" (Benedict \& McMahon, 327 2002).The conceptualisation of GI is strongly linked to planning traditions and a variety of 328 meanings and approaches to its development have emerged on different spatial scales, from 329 national and transnational ecological networks, to regional, urban green space networks and 330 sustainable urban drainage systems at site scale (e.g. Lafortezza, Davies, Konijnendijk, \& Sanesi, 331 2013; Pauleit et al., 2017; Rouse \& Bunster-Ossa, 2013). The concept is often informed by 332 landscape ecological thinking, e.g. the patch-matrix-corridor model (Forman \& Godron, 1986) 333 whereby a holistic consideration of urban landscapes is advocated that includes all open spaces 334 regardless of their origin, use and property.

335 In an urban context, the role of GI as a strategic planning approach has been emphasised based on 336 principles of connectivity, multi-functionality, integration of grey and green elements and that it 337 is planned in a socially inclusive way (Hansen et al., 2016). Such broad principles require further 338 definition for their application in planning. In this context, ecosystem services have been 339 proposed as a suitable concept to operationalise multi-functionality (Hansen and Pauleit, 2014), 340 thus establishing a meaningful link between these two concepts.

341 Ecosystem services can be defined as "the benefits human populations derive, directly or 342 indirectly, from ecosystem functions''(Costanza et al., 1997, p. 253). Later papers have expanded 343 this concept to differentiate between functions, services and benefits (de Groot, Alkemade, Braat, 344 Hein, \& Willemen, 2010; Haines-Young \& Potschin, 2010). Although the 'urban biome' was 345 recognised in some of the original work on ecosystem services (e.g. Costanza et al., 1997), it was 
346 only fully developed in the context of urban areas later, e.g. Stockholm (Bolund \& HunHammer,

347 1999). Such assessments demonstrated that urban ecosystems are associated with a range of

348 benefits for human health and wellbeing (Cilliers et al., 2013; Pickett et al., 2001; 2011; Wangai,

349 Burkhard, \& Müller, 2016).

350 More recently, several authors have argued for a more balanced view on the environment and

351 human wellbeing nexus through the inclusion of ecosystem 'disservices' (Shackleton et al., 2016;

352 von Döhren \& Haase, 2015). They contend that the strident narrative around ecosystem services 353 providing only benefits to humans is one-sided and potentially misleading. A more balanced view

354 would consider ecosystem contributions simultaneously. Consequently, mapping sources, flows 355 and impacts on human wellbeing could be done in an integrated manner with planning and 356 management targeted at optimising benefits and mitigating negative contributions. It also 357 recognises that the same benefit flow might be perceived positively by some, but negatively by 358 others, further emphasising the need to consider disservices alongside ecosystem services

359 (Saunders \& Luck, 2016). Although this need has been recognised more widely, e.g. Pascual et 360 al., (2017), much of the discourse around ecosystem disservices has been in the context of urban 361 ecosystems (Gómez-Baggethun \& Barton, 2013; Lyytimaki \& Sipila, 2009; von Döhren \& 362 Haase, 2015). Importantly, the greater amounts of remnant, unmanaged GI in African cities and a 363 lower capacity to pre-empt and manage disservices could mean that ecosystem disservices are 364 more diverse, more prevalent and have greater impacts than they do in the Global North.

366 This brief characterisation of GI and ecosystem services and disservices provides an overview of 367 key characteristics and lineage. They may have different disciplinary underpinnings but both 368 terms and the frameworks with which they are commonly associated have evolved from 369 considerations which have largely developed in the context of Europe, North America and 
370 Australia (Benedict \& McMahon, 2002; Coutts, Tapper, Beringer, Loughnan, \& Demuzere,

371 2012; Mell, 2016; Pauleit, Liu, Ahern, \& Kazmierczak, 2011). How can what we know now, help

372 to make ideas more sensitive to the requirements of application in other contexts, as in Africa,

373 where urbanisation takes many different forms and there are many complexities which can be

374 overlooked (McHale, Bunn, Pickett, \& Twine, 2013; Myers, 2014)? This includes the somewhat

375 ambiguous nature of urbanisation processes and outcomes which often defy normative models of

376 urban-rural classification and scales of operation enshrined in planning systems (Simone, 2011).

377 It is also unclear how far informality is part of a process of transition or a fundamentally different

378 system of settlement, community and economy which may ultimately prove resilient to change

379 (Hanlon et al., 2017). For this reason, another identified research gap, that of governance

380 (Elmqvist et al., 2013) is pertinent here and links to the need to understand better what sorts of

381 opportunities might come out of informality and the opportunity for local action and change

382 (Anderson et al., 2013).

383 Some of the other research gaps previously identified are also relevant to Part 2 of this paper.

384 They include (after Anderson et al., 2013; Elmqvist et al., 2013; Jackson \& Ormsby, 2017):

385 - Supply-demand gap - how the need for ecosystem services compares with the provision 386 of services, and their inter-relationships, e.g. in terms of 'bundles' of services. Bundles of 387 this type might use thresholds, such as around 'adequate resources', 'benign' 388 environments and 'socio-cultural fulfilment' (Wallace, 2007 in Häyhä \& Franzese, 2014).

389 There is also a need to consider associated social-ecological feedbacks, which itself 390 requires inter-disciplinary perspectives (James et al., 2009) as well as synergies and trade391 offs and how they can be systematically addressed, e.g. via the planning process. 
- Valuation and valuation related gaps - the lack of valuation techniques for some ecosystem services, sometimes also hampered by the lack of evidence of some service types, such as cultural services. They also do not consider valuation from the specific perspective of multi-dimensional poverty in the African context (UNDP, 2014) or the implication of applying valuation forms in contexts where there are weak governance systems and high rates of inequality and corruption.

- Thematic gap - Whilst it is generally recognised that cultural services are underresearched globally, Africa is one of the parts of the world where urban sacred sites have particular significance and diversity (de Lacy \& Shackleton, 2017; Jackson \& Ormsby, 2017). Such sites are associated with mainstream religious practices, but also with other belief systems where humans are considered to be an integral part of the natural world. Sites can also be an important component of cultural traditions and support related practices such as the keeping of oral histories (Jackson \& Ormsby, 2017).

- Geographical gap - Africa is consistently identified as under-researched (e.g. Haase et al., 2014; Wangai et al., 2016). Within Africa studies from South Africa make up the largest proportion of available evidence (Cilliers et al., 2013; du Toit et al., 2018). Given some of the historical drivers to urban form and function in South Africa, not all of its socialecological systems will translate to other African urban areas. 

cities?

416 The review which opens this SI reaffirms the serious paucity of studies on urban GI and 417 associated ecosystem services in Africa (du Toit et al., 2018). Of those that do exist, there are still 418 clear biases geographically and thematically. Geographically, no international peer reviewed 419 articles were found for $60 \%$ of African countries with some urban regions and forms being 420 particularly poorly represented (du Toit et al., 2018). There is little evidence for small and 421 medium sized cities, despite evidence that this is where most of the urban growth and emerging 422 urban poverty in Africa is happening (Anderson et al., 2013). Thematically, most of the existing 423 evidence is centred on provisioning and regulating services with fewer examples tackling cultural 424 services, bundles and trade-offs (du Toit et al., 2018). Similarly, some urban GI elements are 425 better represented than others, with a considerable emphasis on urban agriculture in much 426 existing literature. The papers in this SI start to address some of these identified gaps. 427 Furthermore, they add further depth to knowledge for a subset of particular areas which are 428 relatively well researched.

429 The observation that some services are relatively well represented in the literature is only part of 430 the picture since their actual use by urban populations is still not that well understood 431 (Shackleton et al., 2017). Roy et al. (2018) consider the range of services used by low income 432 dwellers in hazard prone communities in Dar es Salaam, Tanzania. They demonstrate the strong 433 dependencies of local communities on regulating and provisioning services, including for 434 livelihoods and resilience. They also show the importance of diversity in urban GI, with 19 435 different elements identified by local communities as important for quality of life. This 436 importance still needs to be better recognised since communities report reductions in both the 
437 quantity and quality of their local green and blue structures and associated ecosystems. The

438 severe pressure on quality is demonstrated by a reduction in the benefits which can be derived 439 from the same physical spaces (e.g. as a result of reduced fish stocks and seaweed species used

440 for bait, illegal fishing and logging, soil and water contamination and crop failures). Similar 441 situations are likely to be occurring in other cities and local experiences need to be understood 442 alongside evidence of city-wide losses (Lindley et al., 2015). Losses are happening now and are 443 projected to continue. For example in Addis Ababa, Ethiopia, a Business As Usual (BAU) 444 development scenario is estimated to result in the loss of $40 \%$ and $42 \%$ of the city's land area 445 under field crops and vegetable farms respectively between 2011 and 2025 (Abo-El-Wafa, 446 Yeshitela, \& Pauliet, 2017). This is despite evidence that more than half of the produce from 447 these areas is used to support the food requirements of the local urban population, in addition to 448 providing income and employment (Abo-El-Wafa, Yeshitela, \& Pauliet, 2017).

449 Within the provisioning services category alone, uses are highly diverse, going beyond urban 450 agriculture and fuel to harvesting of wild foods and medicines (Shackleton et al., 2017). In South 451 Africa, an average of $64 \%$ of township dwellers across nine small and medium sized urban 452 settlements used at least one wild resource, though this varied greatly across the country 453 (Shackleton et al., 2017). Interestingly, there is evidence that wild resources are purchased for use 454 within relatively high income households. In informal urban settlements, provisioning sources 455 contributed around a third of cash and non-cash income. Provisioning ecosystem functions are 456 therefore important as safety nets to meet dietary needs, as sources of informal employment and 457 as a means of income diversification for some of the very poorest of African urban society. 458 However, if excessive demand and other external pressures such as climate change erode the 459 ability of urban ecosystems to support usage levels, this clearly results in an unsustainable 460 situation. It not only damages important ecosystems and livelihoods but also threatens resilience, 
461 climate adaptation and the potential for the development of future adaptation strategies (Roy et 462 al., 2018).

463 These studies therefore begin to place urban agriculture in the wider context of other ecosystem 464 related benefits and forms of GI which need to be in place to maximise the benefits of urban 465 agriculture and the services it brings (du Toit et al., 2018). Douglas (2016) takes the discussion of 466 multi-functionality further in his perspective piece on flooding in African cities. Drawing on a 467 literature review and evidence generated from 40 years of working on urban flooding issues, he 468 shows how the goals of land and water management systems can be fully compatible with cities 469 maintaining strong urban agriculture sectors. He provides examples of successful flood 470 management schemes performing mutually beneficial regulating and provisioning roles taken 471 from a selection of cases across Africa, covering Accra, Ghana; Kampala, Uganda; Nairobi, 472 Kenya and Bobo-Dioulasso, Burkina Faso. As well as demonstrating values, this bundling of 473 ecosystem services helps to provide the basis for understanding connections and trade-offs. A

474 good example of where trade-off is needed is when considering the impact of different forms of 475 urban development on GI and ecosystem services. Future scenarios for Addis Ababa based on 476 densification (with a doubling of population density) could result in a halving of GI losses 477 compared with BAU (Abo-El-Wafa, Yeshitela, \& Pauliet, 2017). However, this must be traded478 off against a lower availability of benefits for people in low income settlements and the potential 479 intensification of hazards, like heat-waves. Roy et al.'s (2018), qualitative analysis based on the 480 lived experiences of people in low income settlements in Dar es Salaam identifies the value of 481 fresh air and water to support everyday activities, such as for drying clothes and cooking. 482 Uncontrolled development and densification can have the effect of reducing or even cutting off 483 'fresh air' flows from sea breezes and impact human thermal comfort and air quality (Lindley et 484 al., 2015). 
485 This SI also sheds more light on elements of GI which are relatively under-researched in Africa.

486 Where available, gardens can be an important means through which multiple functions and 487 bundles of ecosystem services can be delivered and used (Cilliers et al., 2017). As a pervasive 488 element of cities, they can provide an important foundation for urban GI and associated services.

489 Gardens help to connect larger green spaces in urban areas for example for foraging and 490 pollination. However, connectivity is not always wholly beneficial and must be traded-off against 491 the potential for gardens to become a conduit for the spread of invasive species. Given that 492 gardens represent some of the most bio-culturally diverse spaces in cities (Davoren et al., 2015) 493 they can be associated with high levels of introductions of non-indigenous species. Additionally, 494 knowledge about whether species are invasive or not can be limited (Shackleton \& Shackleton, 495 2016). Nevertheless, the multi-functionality of species used in gardens is important, e.g. trees 496 grown for shade, aesthetics, firewood, medicines and fruits with additional benefits such as 497 carbon sequestration and wider urban cooling (Shackleton et al., 2017).

498 The other core characteristic of gardens is their private ownership and control. Almost three 499 quarters of green cover in the nine small and medium urban areas studied in South Africa by 500 Shackleton et al., (2017) were found to be under private ownership. Proportions are similar to 501 those found in the Global North and elsewhere in the Global South (Gómez-Sal, González502 Garcia, Santovenia, \& Dávila Prado, 2006; Iverson \& Cook, 2000). Gardens are sites of local 503 knowledge of a variety of provisioning and regulating ecosystem functions with strong 504 connections to cultural roles. The types, styles and locations of planting show considerable 505 heterogeneity but also similarities, e.g. between traditional 'homegardens' in more rural settings 506 and their counterparts in more urban settings (Cillers et al., 2017; Davoren et al., 2015). Gardens 507 are shown to provide opportunities for innovation, rapid adaptation and sites for promoting 508 learning around multi-functional ecosystem services and conservation practices. However, 
509 cultural changes operating over generational time scales are leading to a gradual erosion of the

510 necessary indigenous knowledge of the benefits of traditional African garden forms to support

511 future initiatives (Cilliers et al., 2017). This and other challenges to optimise ecosystem service

512 provision in gardens could be addressed by the involvement of various stakeholders, forming a

513 community of practice which could improve social learning as well as having other benefits

514 (Cilliers et al., 2017). If unchecked, the further loss of knowledge provides an additional barrier

515 to sustainable delivery of ecosystem services in Africa to the ones identified in du Toit et al.,

516 (2018). The papers in this SI already provide further knowledge to help address the challenges

517 identified in du Toit et al., (2018), but there is still some way to go (Table 1).

518 Du Toit et al (2018) also touch upon temporal framings highlighting the legacy issues around

519 open lands and the influence of past uses. Unlike in some parts of the world, residents of Africa's

520 smaller urban areas seem to retain an important connection to provisioning ecosystem functions

521 with no reduction in their use with increasing residence time (Shackleton et al., 2017;

522 Schlesinger, Drescher, \& Shackleton, 2015). This demonstrates the importance of GI-related

523 heritage as well as thinking about time in terms of rapid contemporary change. It also

524 underscores that valuation methods which seek simply to monetarize 'current' value without

525 adequate consideration of legacy and future potential, are problematic (Knights et al., 2013).

526 Such methods are likely to under-value the true societal worth of urban GI, either accelerating its

527 decline or leading to inferior replacements, i.e. in terms of ecological, cultural, social and 528 environmental functionality.

529 Despite the importance of private spaces, public GI is still very important for cultural roles, even 530 in smaller cities relatively close to rural areas. Across South Africa there is general dissatisfaction 531 with the availability of public GI for recreation and dissatisfaction increases with increasing 
532 poverty. Almost two-thirds of householders in low income 'RDP' housing estates are dissatisfied

533 compared with around half in more affluent areas. Ironically, though, it is the people in more

534 affluent areas who are more likely to lobby for increases in GI despite higher levels of

535 satisfaction and more public GI to begin with (Shackleton et al., 2017).

536 Public influence over institutions is one means through which issues around GI might be

537 addressed. However, there can be very different levels of state intervention, priorities and levels

538 of planning across Africa (Herslund et al., 2017). Differences have a bearing on how

539 development occurs and also how far and in what ways GI is considered. The extent of

540 involvement of the state and trust in authority - something that tends to be low in the case of

541 South Africa (Shackleton et al., 2017) - will also influence the likelihood of public engagement.

542 In Addis Ababa a traditional top-down approach to planning has been directed into formal

543 housing developments with more than 8000 condominium blocks established in the last ten years

544 (Herslund et al., 2017). There is a growing, but still relatively nascent, recognition of the value of

545 a GI approach. GI features in plans championed by an academic 'green team' co-opted into the

546 plan development process, but there is still work to do to cascade knowledge more fully and

547 coherently through the system and evolve beyond traditional 'beautification' objectives. In Dar es

548 Salaam, it is suggested that there are critical problems with the entire plan-based system due to

549 delays, data and fragmentation (Herslund et al., 2017). The prospect of bringing a GI focus into

550 this arena seems to be very doubtful given the pervasive problems and conflicting priorities. In

551 Addis Ababa authorities are assisted through the land ownership system whereas in Dar es

552 Salaam a mix of private drivers makes for a highly fluid and piecemeal system with many actors

553 involved. In both cities, local communities are not part of the existing regime. Herslund et al.

554 (2017) propose mechanisms to help promote and harness local innovations and experimentations

555 within the prevailing GI and wider planning regimes. Community measures are also frequently 
556 cited in this SI as the key to improving GI-related activity in African cities. Four examples of

557 methods to achieve better community engagement are highlighted here. One is the better

558 involvement of local community organisations in low income settlements (Roy et al., 2018). A

559 second is the wider adoption of special initiatives like health clinic gardens which attract support

560 from a variety of stakeholders leading to co-production of sustainable gardening knowledge and

561 social learning (Cilliers et al., 2017). A third is through influencing the owners of private gardens

562 (Shackleton et al., 2017). The final one is to 'empower urbanites' through payments in wealthier

563 neighbourhoods or time contributions in less wealthy areas (willingness-to-work) (Shackleton et

564 al., 2017; du Toit et al., 2018). Of course, the latter suggestion would need careful consideration

565 from the perspective of ethics and social justice.

566 Community involvement seems particularly important given that a range of GI types are valued

567 by urban residents (from areas with indigenous vegetation through to more managed

568 environments (Shackleton et al., 2017)). Yet Herslund et al. (2017) alert us to the fact that in the

569 regimes they investigated, the interpretation of GI is very narrow. Despite the importance of

570 urban agriculture, only vegetable farms (not field crops) are included in GI planning in Addis

571 Ababa and neither agricultural type is considered in Dar es Salaam. In Addis Ababa urban

572 agricultural land is prime development land for housing condominiums and industrial

573 development. In Dar es Salaam, the lack of recognition of urban agriculture means that it takes

574 place on amenity land as a temporary use, e.g. by road sides. In both cities, consideration of scale

575 and connectivity, so important to the definition of the GI term, is weakly developed. In Dar es

576 Salaam there is considerable potential for local innovation due to existing social norms and rules.

577 Communities are helping to govern the protection of some communal green space areas, even

578 where others are not afforded the same protection and are either used for waste disposal and/or

579 sold off to new arrivals, such as the more peripheral 'back of the areas' green spaces, like those 
580 along riverine corridors (Herslund et al., 2017; Roy et al., 2018). Longer established settlements

581 may need to trade-off the benefits of stronger networks and opportunity for community 582 interventions with a greater proportion of households being rented out to people who may be less 583 well invested in the community, or less able to contribute (Douglas, 2016).

$584 \quad 4.2$ How have related concepts and frameworks been used and might be adapted to provide 585 a better foundation for research and practice in African cities?

586 The papers in this SI use a variety of different definitions of urban GI and ecosystem services.

587 While all hold to the key GI principles of connectivity and multi-functionality it is notable that

588 some, e.g. Shackleton et al., (2017), also discuss differences in application - e.g. from planning 589 perspectives to social-ecological systems and resilience. Furthermore, social, bottom-up 590 processes tend to be emphasised more than government top-down processes.

591 The concept of social-ecological systems is given considerable prominence in many papers due to 592 its emphasis on a coupled consideration of human-environment interactions. This seems 593 particularly appropriate where multi-functionality is high and there are strong links between 594 people and their local environments, as in the case of African cities. The inter-dependency of 595 communities is also highlighted by Douglas (2016). He emphasises the conflicts and trade-offs to 596 be negotiated in the development of successful multi-functional flood management schemes and 597 the human processes which need to be considered. For example, in some flood plain settlements 598 there is a well-established cyclical process of population movement in response to flooding 599 events, echoing the idea of migration as an adaptation practice (Roy et al., 2018). Although 600 floods lead to crop losses and necessitate relocation, such temporary disadvantages are not 601 considered great enough to outweigh the benefits that flood plain locations provide at other times.

602 One solution is to work with this process. However, in doing so there is also a need to consider 
603 knock-on effects on hydrological processes operating from household to catchment scales and the

604 impact that they may have on the frequency and severity of flood events experienced (Douglas, 605 2016).

606 The work in this SI shows that the balance and relative importance of functions are different in 607 different African urban contexts. Studies in Africa also tend to emphasise a different set of core 608 elements to those commonly seen in the international literature (Ahern, 2007; Demuzere et al., 609 2014; Hansen \& Pauleit, 2014). For example, Cilliers et al., (2017) and Shackleton et al., (2017)

610 both emphasise the importance of direct medicinal roles as well as the food and fuel elements of 611 provisioning functions. These functions are in addition to indirect benefits for health and 612 wellbeing, such as the promotion of social interactions and the expression of identity and sense of 613 place.

614 All of the papers emphasise how benefits and systems are related to additional framings and 615 concepts. These include risk (hazard, vulnerability and exposure), adaptation and resilience, 616 social justice, valuation, governance and management, such as integrated water management. 617 Connections are suggestive of the wide range of agendas relevant to urban GI, associated 618 ecosystem services and their management. They point to the variety of benefits and also potential 619 advocates in terms of increasing institutional awareness and identifying synergies.

620 The other reference point is urbanisation and by extension the nature of GI components within 621 African urban areas. Shackleton et al., (2017) refer to urbanisation in Africa as multi622 dimensional, with underlying heterogeneity and complex processes also highlighted (Douglas, 623 2016). In Dar es Salaam, the high level of urban sprawl and agricultural land conversion (Printz 624 et al., 2015) is also reflected in the patterns of urban air temperatures (Lindley et al., 2015) with a 625 less distinct break between urban/rural micro-climates compared to theory developed from classic 
626 studies in the Global North (Oke, 1982). These observations have implications for the

627 representation of related social-ecological systems. Spatial units for social-ecological systems are 628 discussed in Roy et al. (2018). Roy et al. (2018) prefer the use of an urban ecosystem services

629 framing over GI. This is due to the provenance of GI from the planning discipline and the 630 implications that this brings for understanding the nature and evolution of green structures within 631 informal settlements. However, they also go on to call for the development of creative planning 632 and a local approach built on multi-functionality. In principle, this is not too far from the sort of 633 re-imagining of GI for Africa, set out in Herslund et al., (2017). It is also in keeping with other 634 recent calls for better consideration of the intended audience(s) and purpose(s) of GI 635 interventions (e.g. McPhearson et al., 2016).

636 Herslund et al. (2017) use transition theory to analyse existing structures and systems by 637 considering GI functions around water management. They use a definition of GI which 638 emphasises connected ecosystem services and see this as a key principle for understanding how a 639 transition might be made from a situation where spaces are less valued to one where they are 640 appropriately valued as multi-functional parts of the urban system. They suggest that this may be 641 a persuasive way to make the case for how GI can simultaneously help urban residents to tackle 642 the raft of pressing issues they face as well as assist with the process of building wider resilience.

643 For example GI benefits could be seen firstly through the lens of access to fresh water (given that 644 the improved access to, and reliability of, water supplies are an essential basic infrastructural 645 need). By extension, GI benefits can also be recast as some of the other solutions to multi646 dimensional poverty (e.g. as a route to strengthened and diversified livelihoods). This may 647 become especially important in some African contexts, including: where residents, local 648 communities and wider city authorities are working with outmoded or piecemeal information; 649 where GI is difficult to promote due to traditional associations with beautification; and where 
650 there is a wider sentiment in government and other bodies that the requirements for urban GI are

651 less critical compared to those of other demands faced.

652 Based on the examples in this SI, research into GI and urban ecosystem services in Africa 653 employs a range of concepts and frameworks. Their selection depends on the scope and nature of 654 research goals as well as the disciplinary traditions and epistemological foundations of 655 researchers designing and conducting the work. There is still considerable scope to develop 656 frameworks for further research, not least as there is some indication that even the urban 657 ecosystem services concept itself is still not widely used in Africa (Cilliers et al., 2013; 2017).

658 All of the papers provide observations on the specific characteristics of processes and contexts in 659 each case, with clear links to underpinning theory. Some authors have reflected on the suitability 660 of frameworks (e.g. Roy et al., 2018), though this is perhaps not fully resolved.

661 Developing new frameworks is also beyond the scope of this conclusion. However, in rethinking

662 GI and urban ecosystem services from the perspective of the Africa-based research in this SI, a 663 number of suggestions can be made. For developing and applying concepts and frameworks in 664 research and practice, there is a need to:

665 - Pay particular attention to the handling of time and space, scale and their connectivity, 666 particularly to understand rapid and varied rates of change, associated processes and 667 appropriate metrics in the context of land units which are frequently rather indistinct.

668 - Make framings sufficiently adaptable and flexible to incorporate urban heterogeneity, for 669 example in terms of urban form, development patterns and social-ecological systems, 670 including in communities and governance. These may be manifested in specific land 671 management, tenure/ownership practices and traditions or in the closeness with which social 672 and ecological processes are connected in different community, social and spatial contexts. A 
673 failure to recognise this heterogeneity in evidence produced for policy and practice may lead 674 to environmental injustices for vulnerable, disempowered groups.

675 - Demonstrate how the relative importance and value of GI and its ecosystem services may be 676 distinct in urban Africa, for example in terms of the importance of diverse forms of urban 677 agriculture, the role of medicinal functions, and the significance of spiritual and sacred sites 678 representing human relationships with nature. This has implications for what is considered 679 and how it is considered, e.g. in terms of measurement and valuation.

680 - Further recognise how differences in ecosystem disservices are experienced and the nature 681 and importance of disservices in African contexts, how benefits come together, trade-off from 682 one another and can tip from services to disservices, e.g. when the quality of a particular 683 benefit becomes sufficiently degraded.

684 - Consider connecting urban GI benefits and drawbacks to wider factors explaining multi685 dimensional poverty. This could also consider how far quality of life is impacted through 686 pathways affected by GI and ecosystem services such as through livelihoods and safety nets 687 as well as health and wellbeing.

688 - Further develop valuation methods to capture the absolute and relative importance of 689 ecosystem-related functions as life-line infrastructure in different areas (Roy et al., 2018; 690 Douglas, 2016; Lindley et al., 2013), legacies in terms of biodiversity, social and cultural 691 heritage (Cilliers et al., 2017; du Toit et al., 2018) and sites for learning and potential 692 innovation (Cilliers et al., 2017; Herslund et al., 2017). Concerns about the limitations of 693 monetary valuation in a European context (Knights et al., 2013) seem all the more pertinent 694 for Africa given more extreme income and investment inequalities as well as due to weak 695 governance, corruption, a lack of controls and rapid change. Inclusive participatory methods 696 and approaches may be particularly useful, especially where communities need to become the 
697 major agents of change and custodians of their local environment within models like the one

698 proposed by Herslund et al., (2017).

699 - Seek to represent both bottom-up and top-down processes and develop methods and

700 approaches which explicitly handle community bottom-up innovations and initiatives and

701 help to build capacities (du Toit et al., 2018; Herslund et al., 2017; Table 1).

702 - Further recognise the specific needs (including research needs) around institutional capacity

703 building at different scales of governance and how this relates to developing mechanisms for

704 the implementation of GI at all levels (Herslund et al., 2017; Sitas, Prozesky, Esler, \& Reyers,

705 2014). There is a particular need to widen and deepen understanding of the social dimensions

706 of social-ecological systems to help inform action.

707 - Consider non-linear development trajectories and support a re-imagining of urban visions

708 which challenge world views in which GI (e.g. urban agriculture) loss is seen as a positive

709 sign of transition to a more mature urban form, not least given the renaissance of urban

710 agriculture in the Global North (Taylor \& Lovell, 2014).

711 - Seek ways to respond to the full range of opportunities in urban Africa, i.e. from preserving

712 remnant patches of indigenous ecosystem functionality, to establishing/re-establishing multi-

713 functional GI with different scales and forms of development projects.

$715 \quad 4.3$ How far does this SI help to address gaps and what future research agendas emerge?

717 This SI has provided further empirical and theoretical evidence of urban GI and associated 718 ecosystem services in Africa and considers means for their sustainable delivery (du Toit et al., 719 2018). However, there remains a dire shortage of research in and on Africa on these themes in the 720 international academic literature. To some extent this SI has further compounded the bias towards 
721 South Africa, but the research published here has brought new thematic insights in terms of

722 private GI spaces and also improved the evidence base for smaller cities, towns and settlements

723 (Cilliers et al., 2017; Shackleton et al., 2017). The SI has also pulled together evidence from

724 other cities too, notably Addis Ababa and Dar es Salaam (Abo-El-Wafa, Yeshitela, \& Pauliet, 725 2017; Herslund et al., 2017) but also elsewhere in Africa using a range of knowledge bases

726 (Douglas, 2016).

727 In this paper, we also provide the first dedicated analysis of how concepts and frameworks are 728 being applied across a body of research centred on GI and ecosystem services in African urban 729 areas and suggest reference points for future studies. This is important as African variants on 730 ideas developed largely from the perspective of the Global North are yet to emerge. For example

731 do the specific characteristics of African towns, cities and settlements merit a rethinking of terms

732 like urban GI to recognise 'community urban GI' as a distinct marriage of bottom-up community

733 planning with local values of the benefits of multi-functionality and connectivity? To what

734 extent does the concept of GI have a limited role in unplanned contexts, or can 'creative 735 planning' (Roy et al., 2018) be successfully married with a wider appreciation of GI's core tenets

736 of multi-functionality and ecological connectivity as part of an improved understanding of 737 African social-ecological systems? Should urban ecosystem services be a concept more widely

738 promoted in Africa, or rather a new value-based approach developed to help with responding to

739 the challenges of sustainable delivery of benefits? We have considered some of the foundations

740 on which future framings might be develop to address these questions better.

741 There is still a need for more empirical evidence to help inform decision-making and the

742 development of theory on the social and ecological dimensions of urban GI and ecosystem

743 services in Africa. There is little research on social elements, particularly going beyond 
744 recreational roles to consider how strong cultural and spiritual affiliations with nature can be

745 recognised and protected. There is also limited knowledge about how processes operate spatially

746 and socially. Sustainable solutions will need to marry social aspirations and goals for urban life in

747 Africa in the $21^{\text {st }}$ Century with the conservation of high native biodiversity and conflicting

748 ecosystem uses, e.g. the high prevalence of free-roaming urban livestock. Sustainable solutions

749 will inevitably require equal consideration of perspectives and requirements from people across a

750 spectrum of urban neighbourhoods. It may also require the development of novel methods for

751 engagement so as to reach people in communities with low citizen literacy, low local mobility

752 and high transience as well as people living in more established communities with higher levels

753 of education and wealth.

754 Inevitably there is still much to do and a need for foundational as well as applied research. For

755 example, one research direction could be the representation of heterogeneous urban zones around

756 fuzzy memberships rather than crisply delineated zones or the development of other methods to

757 represent the different urban-rural and social gradients seen in Africa, e.g. building on analyses

758 like Zhou et al., 2017. To assist with this task, what sorts of typologies of African urban social-

759 ecological systems can be developed which take account of rates of change, land tenure, 760 community cohesion, transience with the physical structures of green and grey areas? Advancing 761 a multi-level perspective to enhance integration of GI into urban development means that there is

762 a need for the integration of more research on GI governance (Herslund et al., 2016; 2017). On

763 the one hand, such research should increase capacities for strategic decision-making, e.g. in terms

764 of GI networks that influence overall urban development (e.g. Printz et al., 2015; Fohlmeister,

765 Pauleit, Touré, \& Yeshitela, 2015) but on the other hand also retain the capability to support local

766 activities so that multiple roles are supported. 
767 Transdisciplinary approaches are required linking science with practice over a longer-term

768 perspective, i.e. considerably beyond the usual three year funding regimes for research projects

769 and which can make a difference to delivery of the UN Sustainable Development Goals. The idea

770 of establishing "urban learning labs" as arenas for collaborative working and learning, currently

771 popular in international research agendas (Childers et al., 2015), may prove an effective tool for

772 this purpose but they will need to be adapted to the specific requirements of African cities. Here,

773 relatively well researched cities, such as Addis Ababa, Dar es Salaam and Durban could act as

774 lighthouses for wider exchange and the basis for a deeper synthesis of evidence. The

775 interdisciplinary foundations and wealth of perspectives represented in research in some of these

776 cities can provide both a benchmark and a springboard for work elsewhere in Africa. Investment

777 into capacity-building for major stakeholders must be a strong component of such efforts so that

778 outcomes will be continued after the lifetime of particular projects. This may help overcome

779 some of the problems of weak management capacity and a limited knowledge of, and visions for,

780 GI and the ways that local citizens can contribute. A wide range of stakeholders need to be

781 mobilised and engaged for this purpose, including through the development of ways in which

782 plural cultural views can be heard, integrated and conserved within mainstream practice. Only

783 through ambitious, transdisciplinary research endeavours coupled with similarly ambitious

784 funding and support models can urban GI opportunities be realised for a truly sustainable,

785 socially just and uniquely African urban future.

786

787 


\section{References}

790

791

792

793

794

795

796

797

798

799

800

801

802

803

804

805

806

807

808

809

810

811

812

813

814

815

816

817

818

819

820

821

822

823

824

825

826

827

Abo-El-Wafa, H., Yeshitela, K., \& Pauliet, S. (2017). Abo-El-Wafa, H., Yeshitela, K., \& Pauleit, S. (2017). The use of urban spatial scenario design model as a strategic planning tool for Addis Ababa. Landscape and Urban Planning. https://doi.org/10.1016/j.landurbplan.2017.08.004

Ahern, J. (2007). Green Infrastructure for Cities: The spatial dimension. In V. Novotny (Ed.), Cities of the future. Towards integrated sustainable water and landscape management. (pp. 267-283). London: IWA Publ.

Anderson, P. M., Okereke, C., Rudd, A., \& Parnell, S. (2013). Regional Assessment of Africa. In T. Elmqvist, M. Fragkias, J. Goodness, B. Güneralp, P. J. Marcotullio, R. I. McDonald, . . . Wilkinson, Urbanization, Biodiversity and Ecosystem Services: Challenges and Opportunities (pp. 453-460). Dordrecht: Springer.

Assefa, E. (2013). Addis Standard: In Search of a Greener Addis. Retrieved Oct 25, 2017, from http://addisstandard.com/in-search-of-a-greener-addis/

Benedict, M. A., \& McMahon, E. T. (2002). Green infrastructure: smart conservation for the 21st century. Renewable Resources Journal, 20(3), 12-17.

Binder, C. R., Hinkel, J., Bots, P. W., \& Pahl-Wostl, C. (2013). Comparison of Frameworks for Analyzing Social-ecological Systems. Ecology and Society. 18(4): 26. http://dx.doi.org/10.5751/ES-05551-180426

Blanco, H., Alberti, M., Olshansky, R., Chang, S., Wheeler, S. M., Randolph, J., .. Watson, V. (2009). Shaken, shrinking, hot, impoverished and informal: Emerging research agendas in planning. Progress in Planning, 72, 195-250. https://doi.org/10.1016/j.progress.2009.09.001

Bolund, P., \& and HunHammer, S. (1999). Ecosystem services in urban areas . Ecological Economics, 29, 293-301. https://doi.org/10.1016/S0921-8009(99)00013-0

Buizer, M., Elands, B., \& Vierikko, K. (2016). Governing cities reflexively-The biocultural diversity concept as an alternative to ecosystem services. Environmental Science \& Policy, 62, 7-13. https://doi.org/10.1016/j.envsci.2016.03.003

Cavan, G., Lindley, S., Jayeler, F., Yeshitela, K., Pauleit, S., Renner, F., ... and Shemdoe, R. (2013). Urban morphological determinants of temperature regulation ecosystem services in two African cities. Ecological Indicators. https://doi.org/10.1016/j.ecolind.2014.01.025

Cavan, G., Roy, M., Woldegerima, T., Tenkir, E., Yeshitela, K., Kibassa, D., ... Ouédraogo, Y. (2012). International evidence of the ecosystem services of urban green infrastructure in different climate zones. Manchester: CLUVA. Retrieved from http://www.cluva.eu/deliverables/CLUVA_D2.6.pdf

Childers, D. L., Cadenasso, M. L., Grove, J. M., Marshall, V., McGrath, B., \& Pickett, S. A. (2015). Ecology for Cities: A transformational nexus of design and ecology to advance climate change resilience and urban sustainability. Sustainability, 7, 3774-3791. https://doi.org/10.3390/su7043774 
828

829

830

831

832

833

834

835

836

837

838

839

840

841

842

843

844

845

846

847

848

849

850

851

852

853

854

855

856

857

858

859

860

861

862

863

864

865

866

867

Cilliers, S. S., Cilliers, J., Lubbe, C. E., \& Siebert, S. J. (2013). Ecosystem services of urban green spaces in African countries- perspectives and challenges. Urban Ecosystems, 16, 681-702. https://doi.org/10.1007/s11252-012-0254-3

Cilliers, S., Siebert, S. J., du Toit, M. J., Barthel, S., Mishra, S., Cornelius, A., . . Davoren, E. (2017). Health clinic gardens as nodes of social-ecological innovation to promote garden ecosystem services in Sub-Saharan Africa. Landscape and Urban Planning. https://doi.org/10.1016/j.landurbplan.2017.01.011

Costanza, R., D’Arge, R., de Groot, R., Farber, S., Grasso, M., Hannon, B., ... van den Belt, M. (1997). The value of the world's ecosystem services and natural capital. Nature, 387(6630), 253-260. https://www.nature.com/articles/387253a0

Coutts, A. M., Tapper, N. J., Beringer, J., Loughnan, M., \& Demuzere, M. (2012). Watering our cities. The capacity for Water Sensitive Urban Design to support urban cooling and improve human thermal comfort in the Australian context. Progress in Physical Geography, 37(2). https://doi.org/10.1177\%2F0309133312461032

Dark, S. J., and D. Bram. 2007. The modifiable areal unit problem (MAUP) in physical geography. Progress in Physical Geography 31(5): 471-479. https://doi.org/10.1177\%2F0309133307083294

Davoren, E., Siebert, S., Cilliers, S. S., \& du Toit, M. J. (2015). Influence of socioeconomic status on design of Batswana home gardens and associated plant diversity patterns in northern South Africa. Landscape and Ecological Engineering, 12(1). https://doi.org/10.1007/s11355-015-0279-x

de Groot, R. (1987). Environmental functions as a unifying concept for ecology and economics. Environmentalist, 7, 105-109. https://doi.org/10.1007/BF02240292

de Groot, R. S., Alkemade, R., Braat, L., Hein, L., \& Willemen, L. (2010). Challenges in integrating the concept of ecosystem services and values in landscape planning, management and decision making. Ecological Complexity, 7, 260-272. https://doi.org/10.1016/j.ecocom.2009.10.006

de Lacy, P., \& Shackleton, C. (2017). Aesthetic and Spiritual Ecosystem Services Provided by Urban Sacred Sites. Sustainability, 9(1628), 1-14. https://doi.org/10.3390/su9091628

de Smith, M., Longley, P., \& and Goodchild, M. (2013). Geospatial Analysis: a comprehensive guide. Retrieved Oct 12, 2013, from http://www.spatialanalysisonline.com/HTML/?cellular_automata_ca.htm

de Wit, M., Van Zyl, H., Crookes, D., Blignaut, J., Jayiya, T., Goiset, A., \& Mahumani, B. (2012). Including the economic value of well-functioning urban ecosystems in financial decisions: Evidence from a process in Cape Town. Ecosystem Services, 2, 38-44. https://doi.org/10.1016/j.ecoser.2012.08.002

Demuzere, M., Orru, K., Heidrich, O., Olazabal, E., Geneletti, D., Orru, H., . . Faehnle, M. (2014). Mitigating and adapting to climate change: Multi-functional and multi-scale assessment of green urban infrastructure. Journal of Environmental Management, 146, 107-115. https://doi.org/10.1016/j.jenvman.2014.07.025 
868

869

870

871

872

873

874

875

876

877

878

879

880

881

882

883

884

885

886

887

888

889

890

891

892

893

894

895

896

897

898

899

900

901

902

903

904

905

906

907

Díaz, S., Pascual, U., Stenseke, M., Martín-López, B., Watson, R. T., Molnár, Z., . . Shirayama, Y. (2018). Assessing nature's contributions to people. Science, 359(6373), 270-272.

Díaz, S., Demissew, S., Joly, C., Lonsdale, W., Ash, N., \& Larigauderie, A. (2015). The IPBES Conceptual Framework - connecting nature and people. Current Opinion in Environmental Sustainability, 1-16. https://doi.org/10.1016/j.cosust.2014.11.002

Douglas, I. (2016). The challenge of urban poverty for the use of green infrastructure on floodplains and wetlands to reduce flood impacts in intertropical Africa. Landscape and Urban Planning. doi:https://doi.org/10.1016/j.landurbplan.2016.09.025

du Toit, M. J., Cilliers, S. S., Dallimer, M., Goddard, M., Guenat, S., \& Cornelius, S. F. (2018). Urban green infrastructure and ecosystem services in sub-Saharan Africa. Landscape and Urban Planning. https://doi.org/10.1016/j.landurbplan.2018.06.001

Elmqvist, T., Fragkias, M., Goodness, J., Güneralp, B., Marcotullio, P. J., McDonald, R. I., . . . Tidball, K. (2013). Stewardship of the Biosphere in the Urban Era. In T. Elmqvist, M. Fragkias, J. Goodness, B. Güneralp, P. J. Marcotullio, R. I. McDonald, ... Wilkinson, Urbanization, Biodiversity and Ecosystem Services: Challenges and Opportunities (pp. 719-746). Dordrecht: Springer.

Fohlmeister , S., Pauleit, S., Pauleit, C., Touré, H., \& Yeshitela, K. (2015). The Way Forward: Climate Resilient Cities for Africa's Future. In S. Pauleit, A. Coly , S. Fohlmeister, P. Gasparini, G. Jørgensen, S. Kabisch, ... K. Yeshitela (Eds.), Urban Vulnerability and Climate Change in Africa: A Multidisciplinary Approach (pp. 369-399). Dordrecht: Springer.

Ford, A. E., Graham, H., \& White, P. C. (2015). Integrating Human and Ecosystem Health Through Ecosystem Services Frameworks. EcoHealth, 12, 660-671. https://doi.org/10.1007/s10393-015-1041-4

Forman, R. T., \& Godron, M. (1986). Landscape Ecology. New York: John Wiley \& Sons.

Gill, S. E., Handley, J. F., Ennos, A. R., Pauleit, S., Theuray, N., \& Lindley, S. J. (2008). Characterising the urban environment of UK cities and towns: a template for landscape planning in a changing climate. Landscape and Urban Planning, 87, 210-222. http://dx.doi.org/10.1016/..landurbplan.2008.06.008

Gómez-Baggethun, E., \& Barton, D. N. (2013). Classifying and valuing ecosystem services for urban planning. Ecological Economic, 86, 235-245. https://doi.org/10.1016/j.ecolecon.2012.08.019

Gómez-Baggethun, E., Gren, A., Barton, D. N., Langemeyer, J., McPhearson, T., O’Farrell, P., . ... Kremer, P. (2013). Urban Ecosystem Services. In T. Elmqvist, M. Fragkias, J. Goodness, B. Güneralp, P. J. Marcotullio, R. I. McDonald, ... Wilkinson, Urbanization, Biodiversity and Ecosystem Services: Challenges and Opportunities (pp. 175-252). Dordrecht: Springer.

Gómez-Sal, A., González-Garcia, A., Santovenia, P. C., \& Dávila Prado, P. (2006). Private patios, a valuable hidden heritage for tourism development in the city of León, Nicaragua. WIT Transactions on Ecology and the Environment, 97. 
908

909

910

911

912

913

914

915

916

917

918

919

920

921

922

923

924

925

926

927

928

929

930

931

932

933

934

935

936

937

938

939

940

941

942

943

944

945

946

947

Haase, D., Larondelle, N., Andersson, E., Artmann, M., Borgström, S., Breuste, J., . . Elmqvist, T. (2014). A quantitative review of urban ecosystem services assessment: Concepts, Models, and Implementation. AMBIO, 43(4), 413-433. https://doi.org/10.1007/s13280014-0504-0

Haines-Young, R., \& Potschin, M. (2010). The links between biodiversity, ecosystem services and human well-being. In C. Fridand, \& D. G. Raffaelli (Eds.), Ecosystem ecology. A new synthesis (pp. 110-139). New York: Cambridge University Press.

Hanlon, T. M., Krakowka Richmond, A., Shelzi, J \& Myers, G (2017) Cultural identity in the periurban African landscape: a case study from Pikine, Senegal African Geographical Review DOI: 10.1080/19376812.2017.1403333

Hansen, R., \& Pauleit, S. (2014). From multi-functionality to multiple ecosystem services? A conceptual framework for multi-functionality in green infrastructure planning for urban areas. AMBIO, 43(4), 516-529. https://doi.org/10.1007/s13280-014-0510-2

Hansen, R., Werner, R., Luz, A., Szaras, L., Tosics, I., Vierikko, K., . . Pauleit, A. (2016). Advanced urban green infrastructure planning and implemention, EU FP7 Green Surge Deliverable D5.2. Retrieved Dec 26, 2016, from www.greensurge.eu

Häyhä, T., \& Franzese, P. P. (2014). Ecosystem services assessment: A review under an ecological-economic and systems perspective. Ecological Modelling, 289, 124-132. https://doi.org/10.1016/j.ecolmodel.2014.07.002

Herslund, L. B., Jean-Baptiste , N., Jalayer, F., Jørgensen, G., Kabisch, S., Lindley, S., . . . Vedeld, T. (2016). Developing Multiple-Dimensional Assessment of Urban Vulnerability to Climate Change in Sub-Saharan Africa. Natural Hazards, 82, 149-172. DOI: $10.1007 / \mathrm{s} 11069-015-1856-\mathrm{x}$

Herslund, L., Backhaus, A., Fryd, O., Jørgensen, G., Liu, L., Mguni, P., . . Mkupasi, M. (2017). Challenges and opportunities for developing water resilient green cities in Addis Ababa and Dar es Salaam - in search of champions and paths for urban transition. Landscape and Urban Planning.

Howard, E (1898) To-Morrow: A Peaceful Path to Real Reform. Subsequently published as Garden Cities of Tomorrow. London: S. Sonnenschein \& Co., Ltd. 1902. http://www.sacred-texts.com/utopia/gcot/index.htm

Huang, J., Tichit, M., Poulot, M., Darly, S., Li, S., Petit, C., \& Aubry, C. (2015). Comparative review of multifunctionality and ecosystem services in sustainable agriculture. Journal of Environmental Management, 149, 138-147. https://doi.org/10.1016/j.jenvman.2014.10.020

Iverson, L. R., \& Cook, E. A. (2000). Urban forest cover of the Chicago region and its relation to household density and income. Urban Ecosystems, 4, 105-124.

Jackson, W., \& Ormsby, A. (2017). Urban sacred natural sites - a call for research. Urban Ecosystems, 20, 675-681. https://doi.org/10.1007/s11252-016-0623-4

James, P., Tzoulas, K., Adams, M. D., Annett, P., Barber, A., Box, J., ... Ward-Thompson, C. (2009). Towards an integrated understanding of green space in the European built 
948

949

950

951

952

953

954

955

956

957

958

959

960

961

962

963

964

965

966

967

968

969

970

971

972

973

974

975

976

977

978

979

980

981

982

983

984

985

986

987

environment. Urban Forestry \& Urban Greening, 8, 65-75.

https://doi.org/10.1016/j.ufug.2009.02.001

Jemaneh, Y. (2017). The Ethiopian Herald. Ethiopia: Addis Ababa to Establish New Public Parks. Retrieved Oct 25, 2017, from http://allafrica.com/stories/201707280535.html

Knights, P., Admiraal, J., Wossink, A., Banerjee, P., O’Neill, J., \& Scott, M. (2013, Aug). Economic Environmental Valuation: An Analysis of Limitations and Alternatives. Retrieved Oct 26, 2017, from EU BIOMOT project: http://www.biomotivation.eu/docs/BIOMOT_WP1_Deliverable_1.1-FINAL-16.08.13.pdf

Knippenberg, L., Scott, M., O' Neill, J., Drenthen, M., Troha, T., Rado, R., \& Samo, T. (2015). A New Theory of Motivation:an interdisciplinary perspective. Nijmegen: The BIOMOTproject: Institute for Science Innovation.

Lafortezza, R., Davies, C., Konijnendijk, C. C., \& Sanesi, G. (2013). Green infrastructure as a tool to support spatial planning in European urban regions. J. Biogeosciences. For., 6 , 02-108. doi: 10.3832/ifor0723-006

Lindley, S. J., Gill, S. E., Cavan, G., Yeshitela, K., Nebebe, A., Woldegerima, T., . . Sankara, B. T. (2015). Green Infrastructure for Climate Adaptation in African Cities. In S. Pauliet, A. Coly, S. Fohlmeister, P. Gasparini, G. Jorgenson, S. Kabisch, ... K. Yeshitela (Eds.), Urban Vulnerability and Climate Change in Africa (pp. 107-152). Springer International Publishing.

Lindley, S., Gill, S., Yeshitela, K., Woldergerima, T., Nebebe, A., Pavlos, A., ... Koome, D. N. (2013). A GIS based assessment of the urban green infrastructure of selected case study areas and their ecosystem services. Retrieved Dec 1, 2016, from http://www.cluva.eu/deliverables/CLUVA_D2.8.pdf

Lupala, J. (2002). Urban Types in Rapidly Urbanizing Cities: Analysis of Formal and Informal settlements in Dar es Salaam, Tanzania. . Sweden: Unpublished PhD thesis. Department of Infrastructure and planning. Division of Urban Studies, Royal Institute of Technology.

Lyytimaki, J., \& Sipila, M. (2009). Hopping on one leg - the challenge ofecosystem disservices for urban green management. Urban Green, 8, 309-315. https://doi.org/10.1016/j.ufug.2009.09.003

Mace, G. (2014). Whose conservation? Science, 345, 1558-1560.

Maruani, T., \& Amit-Cohen, I. (2007). Open space planning models: A review of approaches and methods. Landscape and Urban Planning, 81, 1-13. https://doi.org/10.1016/j.landurbplan.2007.01.003

McConnachie, M. M., \& Shackleton, C. M. (2010). Public green space inequality in small towns in South Africa. Habitat International, 34, 244-248. https://doi.org/10.1016/j.habitatint.2009.09.009

McConnachie, M. M., Shackleton, C. M., \& McGregor, G. K. (2008). The extent of public green space and alien plant species in 10 small towns of the Sub-Tropical Thicket Biome, South Africa. Urban Forestry and Greening, 7, 1-13. https://doi.org/10.1016/j.ufug.2007.12.003 
988

989

990

991

992

993

994

995

996

997

998

999

1000

1001

1002

1003

1004

1005

1006

1007

1008

1009

1010

1011

1012

1013

1014

1015

1016

1017

1018

1019

1020

1021

1022

1023

1024
McHale, M. R., Bunn, D. N., Pickett, S. T., \& Twine, W. (2013). Urban ecology in a developing world: why advanced socioecological theory needs Africa. Front Ecol Environ., 11(10), 556-564. https://doi.org/10.1890/120157

McHarg, I. L. (1969). Design with Nature. New York: John Wiley \& Sons, Inc.

McPhearson, T., Pickett, S. T., Grimm, N. B., Niemelä, J., Alberti, M., Elmqvist, T., .. Q Qureshi, S. (2016). Advancing Urban Ecology toward a Science of Cities. BioScience, 66(3), 198212. https://doi.org/10.1093/biosci/biw002

Meier, R. L. (1976). A stable urban ecosystem. Science, 192(4243), 962-968.

Mell, I. (2016). Global Green Infrastructure: Lessons for successful policy-making, investment and management. London: Routledge.

Millennium Ecosystem Assessment. (2005). Ecosystems and Human Well-being: A Framework for Assessment. Island Press.

Mosha, F. M., \& Mosha, L. H. (2012). Walking in Transforming Housing Cityscape: A Case of Kariakoo Urban Centre in Tanzania. Online Journal of Social Science Research , 1(8), 231-238.

Myers, G. (2014) From expected to unexpected comparisons: Changing the flows of ideas about cities in a postcolonial urban world. Singapore Journal of Tropical Geography 35,104118

O'Farrell, P. J., Anderson, P. M., Le Maitre, D. C., \& Holmes, P. M. (2012). Insights and opportunities offered by a rapid ecosystem service assessment in promoting a conservation agenda in an urban biodiversity hotspot. Ecology and Society, 17(3).

Oke, T. R. (1982). The energetic basis of the urban heat island. Quarterly Journal of the Royal Meteorological Society, 108(455), 1-24.

Openshaw S. 1984. The Modifiable Areal Unit Problem. Geobooks, Norwich, England. Available at http://www.qmrg.org.uk/catmog/index.html\#

Pascual, U., Balvanera, P., Díaz, S., Pataki, G., Roth, E., Stenseke, M., . . Yagi, N. (2017). Valuing nature's contributions to people: the IPBES. Current Opinion in Environmental Sustainability, 26, 7-16. https://doi.org/10.1016/j.cosust.2016.12.006

Pauleit , S., Hansen, R., Rall , E. L., Zölch, T., Andersson, E., Luz, A., . . Vierikko, K. (2017). Urban Landscapes and Green Infrastructure. Oxford Encyclopedia of the Environment.

Pauleit, S., Liu, L., Ahern, J., \& Kazmierczak, A. (2011). Multifunctional green infrastructure planning to promote ecological services in the city. In J. Niemelä (Ed.), Handbook of Urban Ecology (pp. 272-285). Oxford: Oxford University Press.

Pickett, S. T., Cadenasso, M. L., Grove, J. M., Boone, C. G., Groffman, P. M., Irwin, E., . . Warren, P. (2011). Urban ecological systems: Scientific foundations and a decade of progress. Journal of Environmental Management, 92, 311-362.

https://doi.org/10.1016/j.jenvman.2010.08.022 
1025

1026

1027

1028

1029

1030

1031

1032

1033

1034

1035

1036

1037

1038

1039

1040

1041

1042

1043

1044

1045

1046

1047

1048

1049

1050

1051

1052

1053

1054

1055

1056

1057

1058

1059

1060

1061

1062

Pickett, S. T., Cadenasso, M. L., Grove, J. M., Nilon, C. H., Pouyat, R. V., Zipperer, W. C., \& Costanza, R. (2001). Urban ecological systems: linking terrestrial ecological, physical, and socioeconomic components of metropolitan areas. Annu. Rev. Ecol. Syst, 32, 127157. https://doi.org/10.1146/annurev.ecolsys.32.081501.114012

Printz, A., Abo El Wafa, H., Buchta, K., \& Pauleit, S. (2015). USSDM - Urban Spatial Scenario Design Modelling. In S. Pauleit, A. Coly, S. Fohlmeister, P. Gasperini, G. Jorgensen, S. Kabisch, ... K. Yeshitela (Eds.), Urban Vulnerability and Climate Chance in Africa (pp. 259-286). Dordrecht: Springer.

Pullin, A. S., \& Stewart, G. B. (2006). Guidelines for Systematic Review in Conservation and Environmental Management. Conservation Biology, 20(6), 1647-1656. https://doi.org/10.1111/j.1523-1739.2006.00485.x

Raffaelli, D., \& White, P. C. (2013). Ecosystems and Their Services in a Changing World: An Ecological Perspective. Advances in Ecological Research, 48, 1-70. https://doi.org/10.1016/B978-0-12-417199-2.00001-X

Rall, E. L., Kabisch, N., \& Hansen, R. (2015). A comparative exploration of uptake and potential application of ecosystem services in urban planning. Ecosystem Services, 16, 230-242. https://doi.org/10.1016/j.ecoser.2015.10.005

Roberts, D., Boon, R., Croucamp, P., \& Mander, M. (2005). Resource economics as a tool for open space planning in Durban, South Africa. In T. Tryzna (Ed.), The urban imperative (pp. 44-48). Sacramento: California Institute of Public Affairs.

Rouse, D. C., \& Bunster-Ossa, I. F. (2013). Green infrastructure: a landscape approach. Chicago, IL: American Planning Association.

Roy, M., Shemdoe, R., Hulme, D., Mwageni, N., \& Gough, A. (2018). Climate change and declining levels of green structures: Life in informal settlements of Dar es Salaam, Tanzania. Landscape and Urban Planning. https://doi.org/10.1016/j.landurbplan.2017.11.011

Sachikonye, M. (2014). Natural resource use as a coping and adaptation strategy to floods of vulnerable populations in the Eastern Cape. Grahamstown: Masters thesis, Rhodes University.

Saunders, M. E., \& Luck, G. W. (2016). Limitations of the ecosystem services versus disservices dichotomy. Conservation Biology, 30, 1363-1365. https://doi.org/10.1111/cobi.12740

Schlesinger, J., Drescher, A., \& Shackleton, C. M. (2015). Socio-spatial dynamics in the use of wild natural resources: evidence from six rapidly growing medium-sized cities in Africa. Applied Geography, 56, 107-115. https://doi.org/10.1016/j.apgeog.2014.11.013

Schroter, M., van der Zanden, E., van Oudenhoven, A. P., Remme, R. P., Serna-Chavez, H. M., de Groot, R. S., \& Opdam, P. (2014). Ecosystem Services as a Contested Concept: A Synthesis of Critique and Counter-Arguments. Conservation Letters, 7(6), 514-523. https://doi.org/10.1111/conl.12091 
1063

1064

1065

1066

1067

1068

1069

1070

1071

1072

1073

1074

1075

1076

1077

1078

1079

1080

1081

1082

1083

1084

1085

1086

1087

1088

1089

1090

1091

1092

1093

1094

1095

1096

1097

1098

1099

1100

1101
Seto, K. C., Guneralp, B., \& Hutyra, L. R. (2012). Global forecasts of urban expansion to 2030 and direct impacts on biodiversity and carbon pools. Proceedings of the National Academy of Sciences, 109(40), 16083-16088. https://doi.org/10.1073/pnas.1211658109

Shackleton, C. M. (2012). Is there no urban forestry in the developing world? Scientific Research and Essays, 7(40), 3329-3335. DOI: 10.5897/SRE11.1117

Shackleton, C. M., \& Shackleton, R. T. (2016). Knowledge, perceptions and willingness to control designated invasive tree species in urban household gardens in South Africa. Biological Invasions, 18(6), 1599-1609. https://doi.org/10.1007/s10530-016-1104-7

Shackleton, C. M., Blair, A., de Lacy, P., Kaoma, H., Mugwagwa, N., Dalu, M. T., \& Walton, W. (2017). How important is green infrastructure in small and medium sized towns? Lessons from South Africa. Landscape and Urban Planning. https://doi.org/10.1016/j.landurbplan.2016.12.007

Shackleton, C. M., Ruwanza, S., Sinasson Sanni, G. K., Bennett, S., de Lacy, P., Modipa, R., . . . Thondhlana, G. (2016). Unpacking Pandora's Box: understanding and categorising ecosystem disservices for environmental management and human wellbeing. Ecosystems, 19, 587-600. https://doi.org/10.1007/s10021-015-9952-z

Shwartz, A., Turbe, A., Julliard, R., Simon, L., \& Prevot, A.-C. (2014). Outstanding challenges for urban conservation research and action. Global Environmental Change, 28, 39-49. https://doi.org/10.1016/j.gloenvcha.2014.06.002

Simone, A (2011) The Urbanity of Movement: Dynamic Frontiers in Contemporary Africa Journal of Planning Education and Research 31(4) 379-391 https://doi.org/10.1177\%2F0739456X11416366

Sitas, N., Prozesky, H. E., Esler, K. J., \& Reyers, B. (2014). Exploring the Gap between Ecosystem Service Research and Management in Development Planning. Sustainability, 6, 3802-3824. https://doi.org/10.3390/su6063802

Smit, W., \& Parnell, S. (2012). Urban sustainability and human health: an African perspective. Current Opinion in Environmental Sustainability, 4, 443-450. https://doi.org/10.1016/j.cosust.2012.07.004

Taylor, J. R., \& Lovell, S. T. (2014). Urban home food gardens in the Global North: research traditions and future directions. Agriculture And Human Values, 31(2), 285-305. https://doi.org/10.1007/s10460-013-9475-1

The Economics of Ecosystems and Biodiversity (TEEB). (2011). TEEB Manual for Cities: Ecosystem Services in Urban Management. Retrieved Sept 5, 2013, from www.teebweb.org

Tzoulas, K., Korpela, K., Venn, S., Yli-Pelkonen, V., Kazmierczak, A., Niemela, J., \& James, P. (2007). Promoting ecosystem and human health in urban areas using Green Infrastructure: A literature review. Landscape and Urban Planning, 81, 167-178. https://doi.org/10.1016/j.landurbplan.2007.02.001 
1102

1103

1104

1105

1106

1107

1108

1109

1110

1111

1112

1113

1114

1115

1116

1117

UNDP. (2014). Human Development Report 2014: Sustaining Human Progress: Reducing Vulnerabilities and Building Resilience. New York, NY: United Nations Development Programme. Retrieved June 2, 2016, from http://hdr.undp.org/en/content/human-dev

UN-HABITAT. (2014). State of African Cities 2014 , Re-imagining sustainable urban transitions. Nairobi: UN-Habitat.

von Döhren, P., \& Haase, D. (2015). Ecosystem disservices research: A review of the state of the art with a focus on cities. Ecological Indicators, 52, 490-497. https://doi.org/10.1016/j.ecolind.2014.12.027

Wangai, P. W., Burkhard, B., \& Müller, F. I. (2016). A review of studies on ecosystem services in Africa. International Journal of Sustainable Built Environment, 5, 225-245. https://doi.org/10.1016/j.ijsbe.2016.08.005

Yohannes H, Elias E (2017) Contamination of Rivers and Water Reservoirs in and Around Addis Ababa City and Actions to Combat It. Environ Pollut Climate Change 1(2) 116.

Zhou, W., Pickett, S.T.A. \& Cadenasso, M.L. (2017) Shifting concepts of urban spatial heterogeneity and their implications for sustainability Landscape Eco/32: 15. https://doi.org/10.1007/s10980-016-0432-4 
1118 Table 1: Contributions from this SI to understanding and responding to challenges around the

1119 sustainable delivery of urban ecosystem services in Africa.

1120

\begin{tabular}{|c|c|c|}
\hline $\begin{array}{l}\text { Challenge (du Toit } \\
\text { et al., 2018) }\end{array}$ & $\begin{array}{l}\text { Explanation of challenge } \\
\text { (after du Toit et al., 2018) }\end{array}$ & $\begin{array}{l}\text { Selected insights from the rest of this } \\
\text { SI and some of the remaining } \\
\text { challenges }\end{array}$ \\
\hline $\begin{array}{l}\text { Socio-cultural } \\
\text { values, traditions } \\
\text { and perceptions }\end{array}$ & $\begin{array}{l}\text { Lack of knowledge of socio- } \\
\text { cultural values. Challenges } \\
\text { include a lack of relevant } \\
\text { local valuation; monetary } \\
\text { valuation evidence being at } \\
\text { odds with non-monetary } \\
\text { trade systems. }\end{array}$ & $\begin{array}{l}\text { Roy et al.'s (2018) identification of } \\
\text { multi-functionality supports the } \\
\text { consideration of the range of values in } \\
\text { low income settlements. Multiple } \\
\text { benefits are also considered in Cilliers } \\
\text { et al., (2017) and Shackleton, et al., } \\
\text { ( } 2017) \text {. However, the evidence base is } \\
\text { still relatively poor. }\end{array}$ \\
\hline $\begin{array}{l}\text { Lack of capacity and } \\
\text { expertise }\end{array}$ & $\begin{array}{l}\text { A strong chain of } \\
\text { dependencies affecting } \\
\text { capacity from financial to } \\
\text { technological followed by } \\
\text { institutional and } \\
\text { infrastructure-related. Poor } \\
\text { awareness levels \& the need } \\
\text { for education. }\end{array}$ & $\begin{array}{l}\text { Herslund et al. (2017) propose novel } \\
\text { governance frameworks with Cilliers et } \\
\text { al., (2017) identifying the role for } \\
\text { health clinic gardens and Roy et al. } \\
\text { (2018) demonstrating the role of } \\
\text { community based and other } \\
\text { organisations. }\end{array}$ \\
\hline Governance, urban & Lack of coordination and & Douglas (2016) identifies the lack of \\
\hline
\end{tabular}




\begin{tabular}{|c|c|c|}
\hline $\begin{array}{l}\text { planning and social } \\
\text { inequality }\end{array}$ & $\begin{array}{l}\text { cooperation at different } \\
\text { scales among stakeholder } \\
\text { groups and boundaries; lack } \\
\text { of ownership and tenure } \\
\text { information and therefore } \\
\text { the identification of rights. }\end{array}$ & $\begin{array}{l}\text { holistic planning as a further challenge. } \\
\text { A range of scales are covered in the SI. } \\
\text { Herslund et al., (2017) provide possible } \\
\text { structures and processes for improving } \\
\text { governance. }\end{array}$ \\
\hline $\begin{array}{l}\text { Lack of data and/or } \\
\text { case studies }\end{array}$ & $\begin{array}{l}\text { Lack of evidence to } \\
\text { showcase benefits both for } \\
\text { valuation and also } \\
\text { awareness-raising. Lack of } \\
\text { baseline data to support } \\
\text { activities. }\end{array}$ & $\begin{array}{l}\text { Multiple new perspectives are given on } \\
\text { some of the same cities based on } \\
\text { international research projects. } \\
\text { However, the strengths of a rich } \\
\text { evidence base is countered by the } \\
\text { difficulties using evidence generated } \\
\text { using different terms, methods and } \\
\text { definitions. Despite other major } \\
\text { initiatives for compiling evidence and } \\
\text { emerging evidence for smaller cities } \\
\text { (Shackleton, et al., 2017), there is still } \\
\text { a limited base in Africa especially } \\
\text { beyond South and East Africa. }\end{array}$ \\
\hline $\begin{array}{l}\text { Ecosystem } \\
\text { disservices }\end{array}$ & $\begin{array}{l}\text { Urban GI is related to some } \\
\text { disservices - whether } \\
\text { perceived or experienced. A } \\
\text { range of risks are identified }\end{array}$ & $\begin{array}{l}\text { Disservices may be a result of the } \\
\text { degradation of green and blue spaces } \\
\text { and their ecosystems, sometimes as a } \\
\text { result of inappropriate use (Roy et al., }\end{array}$ \\
\hline
\end{tabular}




\begin{tabular}{|c|c|c|}
\hline & $\begin{array}{l}\text { (fire, drowning, criminal } \\
\text { activity, contamination). }\end{array}$ & 2018). \\
\hline $\begin{array}{l}\text { Spatial trade-offs } \\
\text { and conflicts }\end{array}$ & $\begin{array}{l}\text { Examples given include the } \\
\text { trade-off between food } \\
\text { production and flood } \\
\text { reduction. }\end{array}$ & $\begin{array}{l}\text { Douglas (2016) demonstrates the } \\
\text { spatial social-ecological processes } \\
\text { associated with urban agriculture and } \\
\text { flood management. The example of } \\
\text { different urban development scenarios } \\
\text { is also explored including possible } \\
\text { consequences (Abo-El-Wafa, } \\
\text { Yeshitela, \& Pauliet, 2017; Roy et al., } \\
\text { 2018) }\end{array}$ \\
\hline Climate Change & $\begin{array}{l}\text { Lack of local data hampers } \\
\text { mitigation and adaptation } \\
\text { responses. }\end{array}$ & $\begin{array}{l}\text { Roy et al. (2018) discusses the role of } \\
\text { urban ecosystem services for resilience } \\
\text { and climate adaptation. However, there } \\
\text { is still only a limited evidence base } \\
\text { exploring how urban ecosystem } \\
\text { services will be affected by climate } \\
\text { change. }\end{array}$ \\
\hline
\end{tabular}

